\title{
Factors that Influence Undergraduate Students' Choice of a University: A Case of Botho University in Botswana
}

\author{
Norman Rudhumbu, $\mathrm{PhD}$ (Corresponding author) \\ Botho University, Gaborone, Botswana \\ E-mail: Norman.rudhumbu@bothouniversity.ac.bw
}

Avinash Tirumalai \& Babli Kumari

Botho University, Gaborone, Botswana

Received: January 9, 2017 Accepted: January 13, 2017 Published: March 25, 2017

doi:10.5296/ijld.v7i2.10577

URL: https://doi.org/10.5296/ijld.v7i2.10577

\begin{abstract}
The purpose of this study was to determine factors that influenced decisions of undergraduate students' choice of a university to study at. Botho University was used as a case study. Studies show that universities are currently confronted with both the decrease in student enrolments and high competition for those students between institutions. As a result of these twin challenges, it is of critical importance that factors that influence students' choices of universities are investigated to enable effective planning of student recruitment strategies. The study employed a descriptive survey design that employed a structured questionnaire for data collection. Simple random sampling procedure was used to select a sample of 300 participants from a population of 1240 Botho University undergraduate students. Collected data was analysed using SPSS version 22. Results of the study showed that factors that include academic programmes offered, image and reputation of the institution, advertising, career fairs, quality of staff, employment prospects of graduates from the institution had a very high influence on the decision by students to choose Botho University as an institution to study at. Factors such as tuition fees, chance of getting scholarships and campus visits did not have a very high influence.
\end{abstract}

Keywords: Factors, institutional characteristics, marketing strategies, undergraduate students, university. 


\section{1l Macrothink}

\section{Introduction}

The higher education environment is currently seized with the twin challenges of fewer students who are now able to be sponsored by the Botswana government and high competition for these students among universities (Harden, Davis \& Mengersen, 2014). As of year 2009 there were around 276 tertiary institutions (Botswana Training Authority, 2009) in Botswana, and increasing, competing for the same market of students in a country with a population around 2 million people (Central Statistics Office, 2016). Such a state of affairs calls for management in these higher education institutions to have some strong knowledge of factors that influence how students choose universities to study at. The above is confirmed by Ming \& Kee (2010) and also Avram (2014) who both argue that the studying of factors that influence students' college choices of universities to study at should be treated as a critical component in enhancing institutional marketing strategy planning for student recruitment. On the part of students, decisions to enroll at particular universities are also very important in the students' life (Avram, 2014), as their future career is built around the education they receive from such institutions. Literature shows that any misinformed choice could ruin the student's life completely.

\subsection{Conceptual Framework}

Studies show that factors that influence the decisions of students to choose universities to study at vary from student to student though there are some commonalities here and there (Yamamoto, 2006). These factors are grouped into two categories namely institutional characteristics and communication/marketing strategies (Ming \& Kee, 2010). Institutional factors include reputation, location, study programmes, educational facilities, tuition fees, employment opportunities, and availability of scholarships at the institution (Ming \& Kee, 2010). With regards to marketing or communication strategies, advertising, campus visits, institutional representatives vising high schools, and career fairs, are some of the factors that influence students' decisions on which universities to study at (Ming \& Kee, 2010; Domino et al, 2006). Napompech (2011) also mentions expertise of lecturers, variety of courses offered, and convenience of travel as some of the predictors of students' decisions to choose a particular university to study at.

Based on the above factors, a conceptual framework that highlights the relationship between factors and decision to choose a university is as shown in Figure 1. 


\section{Macrothink

Independent Variables

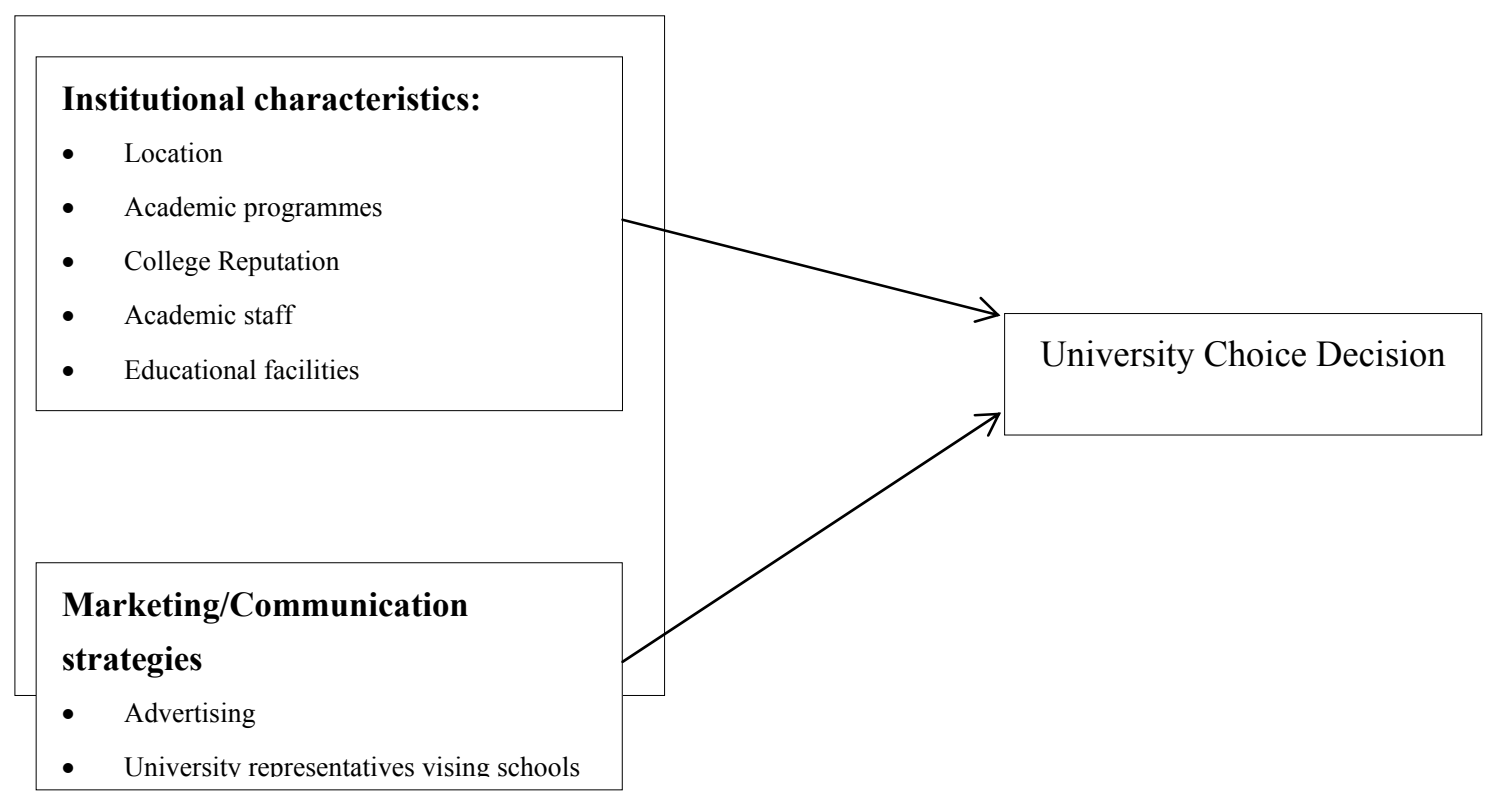

Figure 1. Conceptual framework: Student choice

influencing factors (Ming \& Kee, 2010: 55)

\section{Previous studies on factors influencing student decisions on university choices}

A number of studies have shown that there are a number of factors related to personal and individual characteristics of students, the role of other people, students' perceptions about value and costs, as well as institutional characteristics that influence students' decisions to choose a university for study (Fernandez, 2010). A study by Yusof et al (2008) found that availability of the required programmes and financial assistance such as scholarships were some of the influential factors in the way students decide to choose a particular university. Other studies for example by Ariffin et al (2008) and also Keling et al (2007) found that marketing strategies were influential while a study by Ismail (2009) and also by Keling (2006) found that institutional image and reputation, tuition fees, and academic programmes had a high explanatory power on how students decide on which university to study at. The importance of quality, type and variety of academic programmes as well as the presence of distinguished teaching staff were factors raised in a study by Hsieh (2010) as having a moderating effect on students' decisions to choose a university to study. Ivy (2008) in her study also found that educational facilities as well as conveniences such as parking areas and sporting facilities had a significant predictive influence on students' decisions to choose a university.

Shanka et al (2006), Beneke et al (2010) and also Karl and Yousefi (2009) in their different studies also found that location of the institution as well as opinions of other people such as parents, friends, teachers and others had significant moderating influence on how students choose universities to study at. Mubaira and Fatoki (2012) in their study found that access to learning facilities such as information communication technologies (ICT), cultural diversity, international partnerships, institutional social life, admission requirements, flexible study modes, and campus attractiveness had significant influence on how students make their 
decisions about which university to choose for studies. Moogan (2011) in his study also cited the desire to just get a degree as the main factor while Kusumawati et al (2010) in their study found that marketing (especially the marketing mix), had a significant influence on how students choose universities to study at.

In their study on factors moderating students' decisions on choosing universities to study at, Agrey and Lampadan (2014) found that the following categories of factors had a significant impact on the decision-making processes of students when choosing a university to study at: i) support systems that include both physical (bookshops and counseling offices) and non-physical (availability of scholarships, credit transferability, etc.), ii) the learning environment which relates to the presence of modern learning facilities, institutional reputation, library, computer labs, affordable tuition fees, etc., iii) job prospects of graduates leaving the university, iv) strong student life programmes such as health care, residential accommodation, and extra-curricular activities, v) safe and friendly environment which relates to a safe campus and supportive staff. The above factors were also highlighted in a studies by Baharun et al (2011), Hagel and Shaw (2008), Cokgezen (2012), and Ciriaci \& Muscio (2011). In yet another study, Proboyo and Soedarsono (2015) as well as Kusumawati et al (2010) found that parents played a significant role on how students (their children) chose a university to study at. The influence of parents is also highlighted in a study by Aguado, Laguador and deligero (2015) whose results showed that because parents are the financiers of their children's education, they have a significant influence on where their children go for higher education.

\section{Research Methodology}

\subsection{Research Design}

A descriptive survey research design was used in this study. The importance of survey designs is that surveys are useful in describing the characteristics of a large population and with this broad capability, ensure a more accurate sample to gather targeted results in which to draw conclusions and make important decisions (Salaria, 2012).

\subsection{Participants}

A sample of 300 participants from a population of 1240 undergraduate students of the year 2016 cohort at Botho University were selected to participate in the study. The participants were to indicate the factors they took into consideration or that influenced their decisions to choose Botho University as a university to study at. Simple random sampling strategy was used for selecting the participants. Simple random sampling also referred to as probability sampling, is method of selecting participants so that each member of the population has an equal chance of being selected (Creswell, 2015).

\subsection{Instrumentation}

A structured questionnaire that employed a 5-point Likert scale was used for data collection. The 5 points of the Likert scale which was used to measure how much influence each of the identified factors had on students' college choice decisions ranged from Very High Influence (VHI) - 5, High Influence (S) - 4, Slight Influence (SI) - 3, No Influence (NI) - 2, to No Influence at all (NIA) - 1 


\section{Macrothink}

International Journal of Learning and Development

ISSN 2164-4063 2017, Vol. 7, No. 2

\subsection{Procedure}

The questionnaire was first subjected to reliability and validity testing before being administered. In terms of reliability, internal consistency reliability of the instrument was tested using the Cronbach alpha coefficient $(\alpha)$. Results showed that $\alpha=0.74$ which showed that the instrument was reliable enough to be used in the study. With regards to validity testing, the instrument was tested for content validity by being subject to expert opinion. Recommendations of experts were incorporated into the final instrument. 300 questionnaires were administered to the undergraduate students and 296 were returned giving a return rate of $98.7 \%$.

\subsection{Data Analysis}

Descriptive statics were used for data analysis. Collected data was summarised using a table and graphs as part of data analysis. For ease of analysis, the five different response options of Very High Influence (VHI), Highly Influence (HI), Slight Influence (SI), No Influence (NI) and No Influence at All (NIA) were summarised into three components namely VHI $+\mathrm{HI}=$ HI, NIA + NI $=$ NI, with the third component being SI.

\section{Data Analysis}

\subsection{Analysis of Demographic Variables of Respondents}

The demographic variables of respondents explored in this study included age, gender, experience in running a business and whether the respondent owned a business. Results are shown in Table 1.

Table 1. Demographic data

\begin{tabular}{|c|c|c|}
\hline SN & Biographic factor & Response (\%) \\
\hline \multirow[t]{4}{*}{1} & Age & \\
\hline & $18-22$ yrs & 93.8 \\
\hline & $23-28$ yrs & 5.6 \\
\hline & $28^{+} \mathrm{yrs}$ & 0.6 \\
\hline \multirow[t]{3}{*}{2} & Gender & \\
\hline & Male & 52 \\
\hline & Female & 48 \\
\hline \multirow[t]{4}{*}{3} & Experience in running a business & \\
\hline & $0 \mathrm{yrs}$ & 92.1 \\
\hline & $1-5 \mathrm{yrs}$ & 7.9 \\
\hline & More than 5 yrs & 0 \\
\hline \multirow[t]{3}{*}{4} & Own a business & \\
\hline & Yes & 8.5 \\
\hline & No & 91.5 \\
\hline
\end{tabular}




\section{Macrothink}

Table 1 shows that most of the most of the students were aged between 18 and 22 years (93.8\%) with very few aged between 23 and 28 years $(5.6 \%)$ and above 28 years $(0.6 \%)$. This further shows that most of the first year undergraduate students at this institution were young adults. Results in Table 1 also show that there were more male undergraduate students $(52 \%)$ as compared to female undergraduate students (48\%) of the 2016 cohort. Most of the students (92.1\%) did not have experience of running a business while only $7.9 \%$ had up to 5 years of experience of running a business. None of the students had more than 5 years of running a business. With regards to owning a business, most of the students $(91.5 \%)$ had never owned a business before while only $8.5 \%$ had owned a business of one form or another.

\subsection{Analysis of Institution-Related Factors}

The study showed that there are a number of institutional factors that influence prospective students' decisions to select particular universities for study as shown in Figure 2. Among such university or institutional factors include location of the institution, academic programmes offered, image and reputation of the institution, quality of staff, quality of educational facilities, tuition fees, possibility of getting a scholarship, and prospects of employment of graduates.

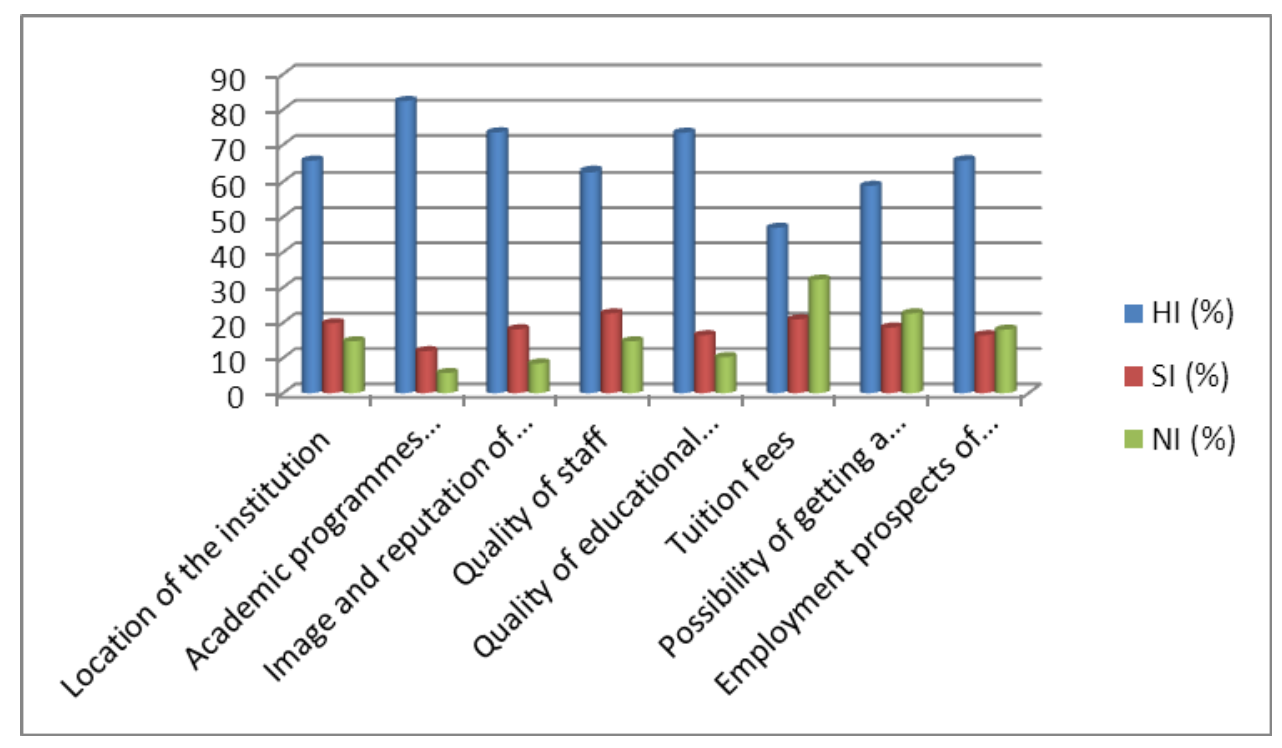

Figure 2. Institutional factors

Results in Figure 2 show that institutional factors play a significant role in influencing the decision of students to enroll at the institution. More specifically, results show that $65.5 \%$ of students were influenced by the location of the institution when compared to $34.5 \%$ who were either slightly influenced or not influenced at all. $82.5 \%$ of the students were influenced by the academic programmes offered by the institution when compared to $17.5 \%$ who either were slightly influenced or not influenced at all. $73.5 \%$ of the students indicated that they were their decision to enroll at the institution were highly influenced by the image and reputation of the institution when compared to $26.5 \%$ whose decisions were either slightly or not influenced at all by the image and reputation of the institution. $62.7 \%$ of the students 


\section{Macrothink}

indicated that their decisions to enroll at the institution were highly influenced by the caliber of staff at the institution when compared to $37.3 \%$ whose decisions were either slightly or not influenced at by the caliber of staff at the institution. $73.4 \%$ of students indicated that their decisions to enroll at the institution were highly influenced by the quality of educational facilities such as classrooms while $26.6 \%$ indicated that their decisions were either slightly or not influenced at all by the quality of facilities. $58.8 \%$ of the students enrolled at the institution with the belief that they may get scholarships while $41.2 \%$ had a slight belief or none at all about getting scholarships. $65.6 \%$ of the students felt that students at the institution had higher chances of getting employed hence their decision to enroll at the institution while $34.5 \%$ either slightly or do not consider at all the employment prospects of students from the institution.

\subsection{Analysis of Marketing Factors of the Institution}

Marketing factors that include advertising, school tours by university staff, career fairs and campus visits by prospective students have an influence on the decisions of students to select a university to study at.

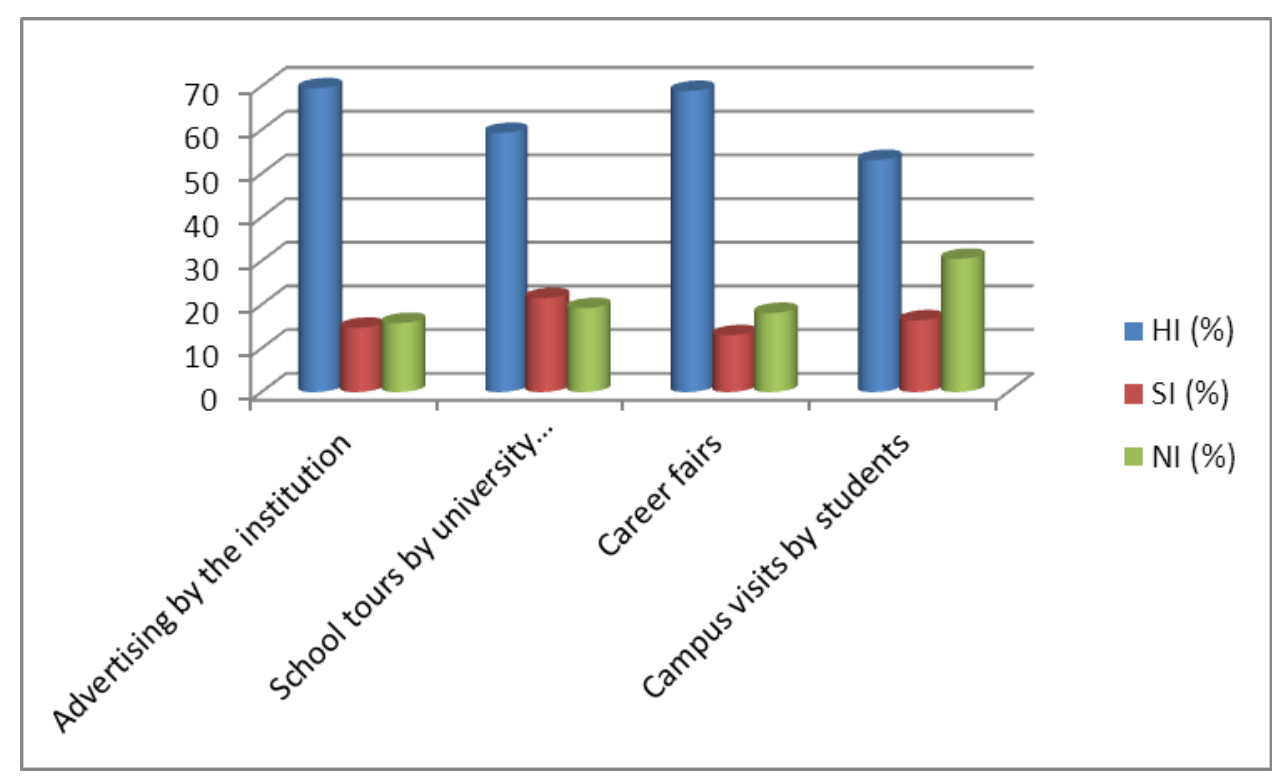

Figure 3. Marketing factors

Results in Figure 3 show that $69.5 \%$ of students believed that advertising by the institution highly influenced their decision to enroll at the institution while $30.5 \%$ of the students did not believe so. $59.3 \%$ of the students believed that the visits by university marketing representatives to their secondary school institutions to talk to them about the university and its programmes highly influenced their decisions to enroll at the university. $19.2 \%$ of the students did not believe so while $21.5 \%$ of the students slightly believed so. Career fairs were considered as highly influential by most students $(69.9 \%)$ in their choice to select the institution for studies. $13 \%$ of the students felt careers fairs had a slight influence while $18 \%$ of the students felt that career fairs did not influence their decisions to enroll at the institution. $53.1 \%$ of student believed that visiting the university campus and seeing the facilities 
available highly influenced their choice of the university while $30.5 \%$ of the students felt the visits did not influence their decisions at all and $16.4 \%$ of the students also felt that the visits slightly influenced their decisions.

\section{Discussion of Findings}

Results of the study showed that institutional factors have a very high influence on the decisions of students to choose a university to study at. Such institutional factors as shown in this study include location of the institution, quality of staff, quality of academic programmes on offer, image and reputation of the institution, quality of educational facilities, prospects of graduates from the institution getting employed, career fairs, and advertising strategies. Results in this study confirm results of earlier studies on factors that influence the decisions of students when selecting a university to study at. A study by Yusof et al (2008) found that availability of the required programmes is a predictor of how students decide to choose a university to study at. Other studies for example by Ariffin et al (2008) and also Keling et al (2007) found that marketing strategies were influential while a study by Ismail (2009) and also by Keling (2006) found that institutional image and reputation, tuition fees, and academic programmes had a high explanatory power on how students decide on which university to study at. Hsieh (2010) also found that the importance of quality, type and variety of academic programmes as well as the presence of distinguished teaching staff were factors that had a moderating effect on students' decisions to choose a university to study. Results of the current study also confirm earlier results in different studies by Agrey and Lampadan (2014), Baharun et al (2011), Hagel and Shaw (2008), Cokgezen (2012), and Ciriaci \& Muscio (2011) which also found that the following categories of factors had a significant impact on the decision-making processes of students when choosing a university to study at: i) support systems that include both physical (bookshops and counseling offices) and non-physical (availability of scholarships, credit transferability, etc.), ii) the learning environment which relates to the presence of modern learning facilities, institutional reputation, library, computer labs, affordable tuition fees, etc., iii) job prospects of graduates leaving the university, iv) strong student life programmes such as health care, residential accommodation, and extra-curricular activities, v) safe and friendly environment which relates to a safe campus and supportive staff.

\section{Conclusions}

A number of conclusions were made based on the above results. First, it was concluded that characteristics of a university that include the quality of staff, academic programmes, educational facilities such as classrooms, location of the institution, as well as employability of graduates, have a high influence on how students choose a university to study at. Second, it is concluded that the choice of which marketing strategies to use by universities is important in influencing students' decisions on the choice of a university to study at. It is further concluded that marketing strategies that have a higher probability of enhancing a university's chances of being selected as a university of choice by prospective students include participation in career fairs and advertising. 


\section{References}

Agrey, L. \& Lampadan, N. (2014). Determinant factors contributing to student choice in selecting a university. Journal of Education and Human Development, 3(2), 391-404.

Aguado, C. L., Laguador, J. M. \& Deligero, J. C. L. (2015). Factors affecting the choice of school and students' level of interest towards Maritime programmes. Asian Journal of Science, 11(21), 231-239.

Ariffin, A. A., Ahmad, A. H., Ahmad, M. S. \& Ibrahim, M. A. (2008). Determining decision-making styles and demographic differences in selecting higher education services among Malaysian. International Journal of Business and Society, 9(1), 1-18.

Avram, E.M. (2014). Higher education Students choice influencing factors. Retrieved $10^{\text {th }}$ September, 2016, from ftp://ftp.repec.org/opt/ReDIF/RePEc/hmm/v1i1/6/7.pdf

Baharun, R., Awang, Z., \& Padlee, S. F. (2011). International students' choice criteria for selection of higher learning in Malaysian private universities. African Journal of Business Management, 5, 4704-4714.

Beneke, J. \& Human, G. (2010). Student recruitment marketing in South Africa - An exploratory study into the adoption of a relationship orientation. African Journal of Business Management, 4(4), 437-447.

Botswana Training Authority. 2009. Registration of Private Higher education Institutions in Botswana. Retried from www.bota.org.bw. [Accessed: 23rd January 2013].

Ciriaci, D. \& Muscio, A. (2011). University choice, research quality and graduates' employability: Evidence from Italian national survey data. AlmaLaurea Working Paper, 49, 1-14.

Çokgezen, M. (2012). Determinants of University Choice: A Study on Economics Departments in Turkey. http://dx.doi.org/ 10.2139/ssrn.2035327

Creswell, J. W. (2015). Educational research: Planning, conducting, and evaluating quantitative and qualitative research, $5^{\text {th }}$ ed. Boston, MA: Pearson.

Domino, S., Libraire, T., Lutwiller, D., Superczynski, S., \& Tian, R. (2006) - Higher education marketing concerns: factors influence students' choice of colleges. The Business Review, Cambridge, 6(2), 101-111.

Fernandez, J. L. (2010). An exploratory study of factors influencing students' college decision in Malaysia: A conceptual framework. International Journal of Business and Social Science, 1(3), 53-58.

Hagel, P. \& Shaw, R. (2008). The Influence of Delivery Mode on Consumer Choice of University. European Advances in Consumer Research, 8, 531-536.

Harden, F., Davis, G., \& Mengersen, K. (2014). The tertiary debate: A case analysis of factors considered when applying for university entry by traditional age school leavers in Brisbane. 
Australian Universities' Review, 56(1), 39-46.

Hsieh, Y. J. (2010). The decision-making process of international students in Taiwan: A case study. Paper presented in The Fifth APAIE 2010 Conference, Griffith University, Australia, April 14-16, 2010. International Islamic University Malaysia (2008). IIUM Annual Report. IIUM Press.

Ismail, N. (2009). Mediating effect of information satisfaction on college choice. Paper presented in Oxford Business \& Economics Conference Program. UK.

Ivy, J. (2008). A new higher education marketing mix: the 7Ps for MBA marketing. International Journal of Educational Management, 22(4), 288-299. https://doi.org/10.1108/09513540810875635

Karl, W. \& Yousefi, F.P. (2009). Factors Influencing Malaysian Students Intention to Study at a Higher Educational Institution. Kuala Lumpur: E-Leader.

Keling, S. B. A. (2006). Institutional factors attracting students to Malaysian institutions of higher learning. International Review of Business Research Papers, 2(1), 46-64.

Keling, S. B. A. Krishnan, A. Nurtjahja, O. (2007). Evaluative criteria for selection of private universities and colleges in Malaysia. Journal of International Management Studies, 2(1), $1-11$.

Kusumawati, A., Yanamandram, V. K., \& Perera, N. (2010). University marketing and consumer behaviour concerns: the shifting preference of university selection criteria in Indonesia. Asian Studies Association of Australia 18th Biennial Conference, Adelaide, South Australia.

Ming, J. \& Kee, S. (2010). Institutional Factors Influencing Students' College Choice Decision in Malaysia: A Conceptual Framework. International Journal of Business and Social Science, 1(3), 53-58.

Moogan, Y.J. (2011). Can a higher education institution's marketing strategy improve the student-institution match?. International Journal of Educational Management, 25(6), 570-589). https://doi.org/10.1108/09513541111159068

Mubaira, T. C., \& Fatoki O. (2012). The Determinants of the Choice of Universities by Foreign Business Students in South Africa. Asian Journal of Business and Management Sciences, 1(8), 9-21.

Napompech, K. (2011). What factors influence high school students in choosing Cram Schools in Thailand? 2011 International Conference on Business and Economics Research, IPEDR 16, Singapore.

Proboyo, A., \& Soedarsono, R. (2015). Influential factors in choosing higher education institutions: A case study of a private higher education in Surabaya. Jurnal Manajemen Pemasaran, 9(1), 1-7. https://doi.org/10.9744/pemasaran.9.1.1-7 


\section{Macrothink}

International Journal of Learning and Development

ISSN 2164-4063 2017, Vol. 7, No. 2

Shanka T., Quintal, V., \& Taylor, R. (2006). Factors Influencing International Students' Choice of an Education Destination-A Correspondence Analysis. Journal of Marketing for Higher Education, 15(2), 31-46.

Salaria, N. (2012). Meaning of the term- descriptive survey research method. International Journal of Transformations in Business Management, 1(6), 1-6. https://doi.org/10.1300/J050v15n02_02

Central Statistics Office. (2016). The population of all cities, towns and urban villages in Botswana by census population. Retrieved $11^{\text {th }}$ September 2016, from http://www.citypopulation.de/Botswana.html

Yamamoto, G. T. (2006) - University evaluation-selection: a Turkish case. The International Journal of Educational Management, 20(7), 559-569.

Yusof, M., Ahmad, S. N. B., Tajudin, M., \& Ravindran, R. (2008). A study of factors influencing the selection of a higher education institution. UNITAR e-journal, 4(2), 27-40.

\section{Copyright Disclaimer}

Copyright for this article is retained by the author(s), with first publication rights granted to the journal.

This is an open-access article distributed under the terms and conditions of the Creative Commons Attribution license (http://creativecommons.org/licenses/by/4.0/). 